\title{
Dissemination of Health Information through Community Empowerment
}

\author{
Saleha Rodiah ${ }^{1}$, Agung Budiono ${ }^{1} \&$ Neneng Komariah ${ }^{1}$ \\ ${ }^{1}$ Library Science Department, Universitas Padjadjaran, Indonesia \\ Correspondence: Saleha Rodiah, Library Science Department, Universitas Padjadjaran, Indonesia. E-mail: \\ saleha.rodiah@unpad.ac.id
}

Received: January 17, 2019

Accepted: February 13, 2019 Online Published: March 30, 2019

doi:10.5539/jsd.v12n2p13

URL: https://doi.org/10.5539/jsd.v12n2p13

\begin{abstract}
The process of information dissemination is a strategic study in information and communication science since a successful information dissemination process will enable to provide significant multiplying effects. This research aimed to identify community empowerment activities in the dissemination of health information to improve the quality of public health in Margajaya village, Ngamprah, West Bandung Regency. The study used a qualitative case study method, by collecting data through observation, unstructured interviews, and literature review. The dissemination of health information used an education strategy in its activities, namely the behavior change through means of education or health promotion, which are efforts or processes to foster awareness, willingness and ability to maintain and improve health. There was involvement of community empowerment agents who received training from relevant agencies, joined voluntarily and committed to participate in health development. The ex-tattoo community is a community that engages in the dissemination of health information. In addition to disposing of its negative image in the village, the community seeks to become a part of empowerment in improving the quality of public health.
\end{abstract}

Keywords: information dissemination, community empowerment, health promotion

\section{Introduction}

Health is one of the essential aspects of an individual's overall quality of life; however, not everyone is aware of and practices health care. Whereas if the community at large has an awareness of the importance of health care, it will benefit the process of disease prevention, increase their health quality, and engage actively in each healthcare management effort.

Law Number 36 of 2009 concerning Health states in article 1 that Health is a healthy state, physically, mentally, spiritually and socially which allows an individual to carry out a fruitful social and economic life." Thus, the measure of health is not only physical, mental, and social aspects, but also includes elements of economic and social productivity.

Also, the Law on Health in Article 52 states the Law on Health, in Article 52 states, the overall health care efforts covers the aspects of promotion, prevention, cure, and rehabilitation. Although in the view of ordinary people current health services are still centered on curative and rehabilitative actions, hence they tend to shift from a health paradigm to a disease paradigm. To achieve health improvement, health care workers may conduct health promotion as a means of revitalizing health education. With the promotion of healthcare, not only will there be a process of public awareness or just providing an increasing general knowledge about health, but also efforts to change behavior.

For this reason, the effort to become a member of a health information literate community is the right of every citizen, as is stated in the Law of the Republic of Indonesia No.36 of 2009 concerning Health, in Article 7 that, everyone has the right to receive balanced and responsible information and education concerning health.

The Guidelines for Implementing Regional Health Promotion as stated in the Decree of the Minister of Health No. 1114 / Menkes / SK / VII / 2005 mention that health promotion strives for improving the community's ability through learning from, by, for, and with the community so that they can help themselves by developing community-based activities following the local socio-cultural conditions and health concerned public policies.

There are two Puskesmas in Ngamprah District, West Bandung Regency, namely the Cimareme and Ngamprah 
Puskesmas. Furthermore, are included in the work area of the Cimareme Puskesmas are six villages namely: Margajaya, Pakuhaji, Tani Mulya, Cilame, Gadobangkong, and Cimareme village. Margajaya Village is a village that has a variety of community organizations, among them is the ex-tattoo community, which helps empower the community, especially in the health sector.

The data above is the basis that to improve public health, the role of community organizations is no less critical it may be more important than the position of community empowerment carried out by external parties. As Parsons et al. stated in Suharto (2014), that empowerment is generally carried out collectively. Moreover, when viewed from the empowering setting it can be categorized into Aras Mezzo, namely empowerment carried out on a group of clients as an intervention, performed through education and training; group dynamics are usually used as a strategy to increase awareness and the ability to solve the problems it faces.

One of the references is a study on the dissemination of health information carried out by Agung Dwi Laksono and Ratna Dwi Wulandari (2011) entitled Analysis of the Potential Dissemination of Health Information through Social Networks: A Case Study in the AIDS Treatment Network Forum. This study measures the effectiveness of information dissemination since information dissemination through social networking media is not tied by the administrative boundaries of a region. The method used is content analysis. The AIDS Care Network Forum consists of members from 20 countries. Members from overseas, even though they live abroad, are mostly Indonesian citizens who live and work abroad, so they use the Indonesian language. The study discusses the trends in the number of users of the AIDS Care Network Forum page, the pattern of total interactions, post quality interactions, and the theme of the post. This study uses the Theory from Rogers which applied its stages in the process of diffusion of innovation in the AIDS Care Network Forum, namely: 1) Knowledge, all members of the forum, if they have read a particular post, will undoubtedly be aware of and know the information; 2) Persuasion, individuals who have received information will indicate favorable or unfavorable attitude. The unfavorable attitude occurs due to differences in perspectives on AIDS prevention methods; 3) Decision, substantially $100 \%$ of members can receive information that is spread in AIDS care networking forums; 4) Implementation, based on comments or incoming posts indicates that there are no members who behave deviant or at risk of AIDS, some are even active in AIDS care groups.; 5) Confirmation, specifically this stage has not been detected correctly in this forum because it has not yet been specifically evaluated.

Furthermore, a study by Anne Ratnasari (2005) entitled: Health Communication: Dissemination of Information on Healthy Lifestyle, focused on the characteristics of messages, communication channels, and the period of the spread of the idea of a healthy lifestyle by applying food combining as an innovation in the field of public health. The results are 1) information on food combining as an innovation in the field of health communication cannot be separated from the views of society, among others, related to relative profit factors, compatibility, and complexity; 2) in the communication channel, food combining nutrition experts use guidelines between personal communication, group communication and mass communication in disseminating health information; 3 ) in the dissemination of food combining information as an innovation requires considerable time and active efforts by nutritionists or health communication consultants so that the public can feel the benefits.

The dissimilarity with previous studies is that this study examines the dissemination of health information regarding the outcome model for health promotion from Nutbeam (2000) in the field of community empowerment. For this reason, this research aimed to identify the method of community empowerment in the dissemination of health information.

\section{Method}

This research used the qualitative research method with a case study approach, to identify and describe in more detail the 'maintaining atmosphere' program as a health promotion strategy. The case study approach is suitable when in a question the subject is influenced by 'how' and 'why,' and if the researcher has little opportunity to control the investigation of occurrences, as the focus of a study lies in a phenomenon within its real-life context (Yin 2008). As Mulyana (2007) points out, the case study is a comprehensive description and explanation of various aspects of an individual, a group, an organization (community), a program, or a social situation. Furthermore, it aimed to obtain a description and explanation of health literacy education by building environmental health behavior from the phase of 'know' to the phase of 'want to' that was carried out by the Cimareme Puskesmas and PKK Cadre of Margajaya village.

The techniques used for collecting data were observation, interview and documentation studies. In this study, the data collection was conducted purposively, that is with specific consideration. For example, the selected persons were regarded as those who knew most about health promotion strategies, primarily as it was related to the development of 'maintaining atmosphere'. 


\section{Results}

\subsection{Health Information for Community Empowerment}

Article 8 of the Health Information System states that: Health Information consists of: a) Information on health efforts; b) Information on health research and development; c) Health financing information; d). Information on human resources for health; e) information on pharmaceutical, medical devices, and food preparations; f) management information and health regulations, and g) information on community empowerment.

Information on community empowerment as referred to in paragraph (1) letter $g$ in the Health Information System is related to information about a) type of community organization that cares about health; and b) the results of community empowerment activities in the health sector, including community mobilization. According to Notoatmodjo (2007: 108), in the field of health, community empowerment is an effort or process to foster awareness, willingness and ability to maintain and improve health.

Moreover, as stated by Notoatmodjo (2014: 90), the World Health Organization (WHO) has classified some strategies as concrete and positive efforts to acquire behavioral changes that are following health norms, namely 1) enforcement; 2) the power of regulation or law, and 3) education. The result of our observations revealed that healthcare workers used health education or promotion methods in performing health awareness activities, commencing with providing health information, in the form of socialization and counseling to village officials and community members Also, working groups at the village and kelurahan level were in charge of handling health problems in each village, at least in the preventive or preventive stages. This could be carried out among others, by socializing the healthy and clean way of life, to every family.

The field results were not surprising, because primarily health workers were provided with knowledge related to public awareness efforts of behaviors that did not support healthy living. Among them is health promotion to revitalize health education. Health promotion activities are not only a process of public awareness or the provision and improvement of the community's knowledge about health but also an effort to change behavior. The World Health Organization (WHO) in the 1986 Ottawa Charter (Notoatmodjo 2007: 23) has formulated that: "Health promotion is the process of enabling people to increase control over, and improve, their health. Thus to reach a state of complete physical, mental, and social, well-being, an individual or group must be able to identify and realize aspirations, to satisfy needs, and to change or cope with the environment."

Health workers, including health promoters from the Cimareme Health Center and village midwives, were assigned to teach environmental health behavior in accordance with the mission statement for health promotion, namely: 1) empower individuals, families, and communities to live healthy lives; 2) fostering a conducive atmosphere or environment in order to create a Clean Healthy Lifestyle (PHBS) in the community; 3) advocacy, for decision and policy makers. Regarding the field of advocacy, , it is usually consulted in advance at the Health Promotion UPT at the West Bandung District Health Office, as it pertains to the authority and communication of the organization.

In its implementation, it is essential to strengthen health promotion strategies with appropriate methods and media as well as availability of suitable human resources. The technique referred to here is the communication method. In principle, empowerment, atmosphere building, and advocacy are in the communication process. Therefore, implementing the communication process requires the right method. The method selection must be performed carefully by paying attention to the packaging of the information, state of the recipient of the information the condition of the recipient of information (socio-demographic) and the context of communication.

In the Guidelines for Implementing Regional Health Promotion as stated in the Decree of the Minister of Health Number 1114/Menkes/SK/VII/2005 is explained that: health promotion is the effort to improve community health through community empowerment so that they can help themselves by developing community-based activities following the socio-cultural conditions and health-related public policies (Ministry of Health 2005).

Self-help means that people can cope with threatening health problems by health prevention, and overcome occurrences by dealing effectively and efficiently. In other words, the community can conduct clean and healthy lifestyles to solve the health problems it faces (problem-solving), both health problems that they suffered from and those that potentially threatened independently (within certain limits).

The dissemination of information, in this case, related to information on the health of the community empowerment subsystem, is a form and method of administering health efforts, at the level of individuals, groups and the broader community in a planned, integrated and sustainable manner. These community empowerment efforts are performed to achieve the maximum level of public health.

In order to achieve the ultimate goal reflected in the definition of health literacy - striving to promote greater 
independence and empowerment between individuals and communities working with us - we need to recognize and understand aspects of education policy, which focuses on overcoming structural barriers to health care.

Behavior is the common result of a variety of internal and external factors causing human behavior becomes complicated due to a wide range of factors. Public health encompasses particularly health education which studies the importance of conduct providing socio-psychological conditions in such a way that individuals or communities behave by the norms of healthy living (Nutbeam, 2000).

\subsection{Agents of Community Empowerment}

Referring to the Minister of Health's Decree No. 128/Menkes/SK/II/200 concerning Basic Policies for Public Health Centers such as the puskesmas is a center for community empowerment. The puskesmas seeks individuals, especially community leaders, families and community members, including the business community to raise awareness, readiness, and capacity. So that they can help themselves and the community to live healthy, actively participate in overcoming health problems including funding, and also take part in the establishment, organization, and monitoring of the implementation of health programs taking into account the conditions and situations, especially the socio-cultural aspects of the local community.

Due to this, Health officials empower the Community Empowerment Cadres (KPM - Kader Pemberdayaan Masyarakat), comprising of volunteers concerned with the quality health improvement of the environment. Cadres were administratively selected by the community, usually on account of particular skills. These skills include the ability to read and write and participate actively in community activities. This was a manifestation of the UKMB (Upaya Kesehatan Bersumberdaya Masyarakat) or the Joint Community -based Health Efforts).

Mubarak (2009) defines health cadres as volunteers who are selected, trusted, and come from the local community, have received health cadre's training as executors, managers, and developers of community activities in in efforts to develop community health and welfare.

The cadres were given training by health care workers at the Subdistrict Level, to be able to identify the causes of health problems which might be based on behavior, knowledge, and social, physical and biological environment, or healthcare service accessibility. Health care workers conducted the training of health cadres based on one of the health promotion missions, namely: Improving community knowledge by conducting counseling, teaching, and coaching as well as reinforcement of human resources to raise awareness - the aptitude and preparedness of the community to live a clean and healthy life.

In performing health literacy education, the knowledge of PKK cadres was sought first in accessing the acquisition and utilization of information, efforts to disseminate health information and health promotion strategies as a means of education. Eventually, these activities led to an increase in the health quality of the people in Margajaya Village. The cadres attempted to use every opportunity for providing counseling on the importance of environmental health. On this occasion, PKK cadres represented the facilitators in group counseling at the posyandu, Dasa Wisma group meetings, social gathering (arisan), recitation (pengajian), village / kelurahan meetings, home visits, and others.

Also, PKK cadres gave an example to the community, as explained by an informant: "I often schedule Sunday mornings for sweeping the streets around the house with my husband's help." This effort was an exemplary form related to the way of responding to the environment, especially the physical environment so that residents of the Margajaya village could apply a health-minded behavior.

\subsection{Communities Involved in Disseminating Health Information}

The Ex-Tatto Community is a community that supports the health information dissemination program in Margajaya Village. The Ex-Tatto community or often called Mas Berto is a place for marginalized people to make changes in a better direction. As the name implies, the majority of the members of this community are tattooed people. Before joining this community, the existence of members of the Ex-Tatto community made people worried. However, after they joined this community, the negative stigma of society slowly faded.

Initially, the name of this community was MasBerto (Tattooed community) and was then changed to the Ex-Tattooed Community by the existing rules. The name 'Eks-Tatto' also has its meaning. The interpretation of the word 'ex' itself in the Indonesian language is 'eks.' Thus the word is used to give the meaning that there is hope to be a better person because it has become an 'ex' of the previous condition which is considered not good. The principle held firmly by this community is doing good whenever and wherever, and upholding the values of courtesy, morals, and morality.

This Ex-Tatto community is an example of a social community that has succeeded in empowering its members. 
Many activities were carried out by this community to help the surrounding community. The primary purpose of this community was to make changes in a better direction, to realize this, Ex-Tatto members often participated and assisted in various community activities.

Some of the activities were assisting in posyandu operations, helping the funeral process of residents, participating in various training programs, working with government agencies both at the village and district level and others. Another desire of this community was to change the negative stigma that was given by the community towards the members of this community who were mostly tattooed.

The community, village officials, PKK cadres, and Cimareme puskesmas have felt the role of the ex-tattooed community in the information dissemination on community empowerment, as mentioned by Ms. Mili who stated: "Ex-tattoo members often help us, including in posyandu activities and health counseling."

Members of this community claimed that joining a community gave rise to various feelings of happiness and kinship. Joining the community also helped members to develop a sense of empathy and care for their fellow human beings and helped members to re-socialize in the community.

\section{Conclussion}

The conclusion is information dissemination of community empowerment is performed by using an education strategy, namely behavior change through the means of health education or promotion, which are the efforts or processes to foster awareness, willingness and ability to maintain and improve health. There is involvement of community empowerment agents who receive training from relevant agencies, who join voluntarily and commit to participate in health development. The 'Eks tatto' community is a community that engages in the dissemination of health information. In addition to disposing of negative images in the community, they also try to be a part of empowerment in improving the quality of public health.

\section{References}

Departemen Kesehatan RI. (2004). Keputusan Menteri Kesehatan RI No. 128/MENKES/SK/2004 tentang Kebijakan Dasar Pusat Kesehatan Masyarakat.

Departemen Kesehatan RI. (2005). Undang-undang No. 36 Tahun 2009 tentang Kesehatan.

Green, G. P., \& Haines, A. (2015). Asset Building \& Community Development (4th ed.). Sage Publishing

Laksono, A. D., \& Wulandari, R. D. (2011). Analisis Potensi Penyebaran Informasi Kesehatan melalui Jejaring Sosial: Studi Kasus pada Forum Jejaring Peduli AIDS. Buletin Pnelitian Sistem Kesehatan, 14(4), 358-365. Retrieved from http://ejournal.litbang.depkes.go.id/index.php/hsr/article/view/1373/2197

Mubarak, W. H. (2006). Pengantar Keperawatan Komunitas 2. Jakarta: Sagung Seto.

Mulyana, D. (2007). Metode Penelitian Kualitatif. Remadja Rosdakarya.

Notoatmodjo, S. (2007). Promosi Kesehatan dan Ilmu Perilaku. Jakarta: Rineka Cipta.

Nutbeam, D. (2000). Health Literacy as a Public Health Goal: a Challenge for Contemporary Health Education and Communication Strategies into the 21st Century. Journal of Health Promotion International, 15(3). https://doi.org/10.1093/heapro/15.3.259

Ratnasari, A. (2008). Komunikasi Kesehatan: Penyebaran Informasi Gaya Hidup Sehat. Mediator: Jurnal Komunikasi, 9(1), 1-12. $\quad$ Retrieved https://ejournal.unisba.ac.id/index.php/mediator/article/view/1136/694

Suharto, E. (2014). Membangun Masyarakat Memberdayakan Rakyat. Cet.5. Bandung: Refika Aditama.

Yin. (2008) Studi Kasus: Desain dan Metode, cet. 8. Jakarta: Raja Grafindo Persada.

\section{Copyrights}

Copyright for this article is retained by the author(s), with first publication rights granted to the journal.

This is an open-access article distributed under the terms and conditions of the Creative Commons Attribution license (http://creativecommons.org/licenses/by/4.0/). 